\title{
Business With China: A Critical Evaluation Of Lure And Challenges
}

Mohamad Sepehri, Jacksonville University, USA Hassan Pordeli, Jacksonville University, USA

\begin{abstract}
This paper examines the significant historical and socio economic development in China over the past quarter century and summarizes the main features of the pre-reform economy and the main strategies adopted by china as it began its quest for economic progress. The paper also evaluates the consequences of China's market reform and the challenges to this new economic power. The objective of the paper is to discuss both opportunities and risks in doing business in China and to provide and understanding of what compels so many firms to so boldly seek to establish a presence in China while taking substantial risks in doing so. The research concludes that, investment and business opportunities in China would outweigh the risk and challenges faced by potential investors. The paper examines the elements contributing to China's reform, including pro market reform, economic growth, and the rate and significance of FDI in china. Investment challenges include: corruption, mostly "unfree" economy, low ranking in ease of doing business, undervalued Yuan, and lack of proper intellectual property rights. The research points to positive indicators such as: China's economic development growth (i.e. GDP growth at $9.9 \%$ in mainland and 12.4\% in Zhejiang); China's entry in WTO - relaxing foreign investment restrictions; infrastructure development - transit, energy, telecommunications, etc.; and the impact of the market reform - China's economic growth rate among the highest recorded during the past three decades. The examination of risks and challenges, reveals (1) the "Driving Forces" for business investment in China which include: rapidly expanding economy; growth in Chinese consumer purchasing power; and economic Power \& other Indicators; and (2) the issues of concern such as: excess capacity in industrial sector, export dependence economy, problem with banking sector, and potential unemployment problem. The paper concludes that - despite potential and clear risks - there are good and legitimate business and investment potential in China and among many factors to consider are: many incentives to consider business opportunities and potential benefits; rising personal income and spending power in China; and increase in per capita income at steady rate of $8 \%$ since 1980 , currently estimated at $\$ 3000$.
\end{abstract}

Keywords: Business Investment in China, Market Reform, Economic Freedom Index, Socio Economic Development, Foreign Direct Investment, Economic Growth

\section{INTRODUCTION}

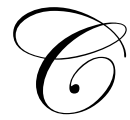

hina is a country in transition - emerging from the cocoons of Marxist-Moist ideology to embrace a new- found confidence in capitalism. The last 30 years have witnessed this amazing transition of the world's most populous nation from an economic backwater to an emerging superpower. Not only has this economic revolution resulted in growth in GDP - perhaps unprecedented in the history of economic development - it also has given China a place in the community of nations.

The business landscape throughout China is changing ever more rapidly. The Chinese leadership has diminished the role of ideology in economic policy and - instead - has embraced a more pragmatic approach on political and socioeconomic change (CIA World Fact Book, 2003). The continuing political transformation combined with social and economic reforms in China have produced considerable impact on world business and 
economy. It seems nearly every international company has a presence - or at least a strategy - for participating in the Chinese market. Yet the risks of doing business in China remain substantial by many conventional standards.

\section{CRITICAL ELEMENTS CONTRIBUTING TO CHINA'S POLITICAL, BUSINESS AND SOCIO ECONOMIC REFORM}

Government: China's government is formed by the National People's Congress (NPC), the highest ranking organization under the constitution. Among wide-ranging power, the NPC supervises the enforcement of the constitution, elects the president and vice president of the country, chooses the premier of the State

Council upon nomination by the president, and elects the president of the Supreme Court. The impetus for current economic growth and prosperity were a series of policy "pronouncements" - in early 1990s - by then Deng Xiaoping to bolster the process of economic reform. Since the market reform initiation, the NPC has elected and supported the candidates who are pro market reform and have continued on the path to western-style capitalism.

Chinese Community Party (CCP): The CCP includes congress and committees from the national to the local level and its structure parallels that of the government. The Central Committee is the CCP's decision-making body and the National Party Congress elects its members. The Central Committee acts as the permanent executive body between sessions of congress. The CCP has been instrumental in supporting the market reform ideas and proposals (Investment Promotion Network, 2005). After Deng Xiaoping's push for economic reform, the $14^{\text {th }}$ Party Congress supported his reform policies by creating a "socialistic

market economy." The Party Congress encouraged continuity in the political system with particular emphasis in economic reform.

Market Reform: By the 1970's, it had become clear that the prevailing economic policies had to change and that China had to adopt capitalistic tendencies in its goal towards economic prosperity (U.S. Dept. of States, 2005). The question that remained was how to enact this transition without causing violent revolution in a country of more than 1.3 billion people with a land mass larger than United States.

It is interesting to note that China has taken a different path from the Soviet Union in its transition towards a market economy (Forbes, 2000). Whereas Russia pursued a rapid and radical transformation to private property and free markets to achieve an irreversibility of its reforms - the so called "shock therapy" - China's market reforms have occurred in a piecemeal, experimental, and graduate manner. Equally intriguing is the fact that while the Soviet Union concluded that its political apparatus, the Communist Party, was a major obstacle to economic reform and had to be abolished; China has sought economic reform under the strong direction of its communist party. Convinced - at least at this stage - that communist dictatorship and a market economy are compatible.

Reforms in China's economy occurred in three waves (Wattanavitukul, 2000). The first wave was directed by Mr. Deng himself in the late 1970's and early 1980's. It consisted of creating a market economy for food, initially by deregulating prices for most food except grain and abolishing the agricultural communes as a unit of production, replacing them with family farms that were more market-driven. After fulfilling their obligatory quotas, farmers could now sell the rest of their produce at market prices, thereby earning a more substantial profit. This resulted in a sharp rise in both output and productivity. Value-added commodities in agriculture increased by $7 \%$ a year while the number of people working in agriculture-related industries decreased due to increased efficiency of production. It laid the groundwork for sustained growth of agricultural output and generated the surplus of rural savings needed to finance the industrialization of China.

The second element of the early Deng reforms consisted of implementing an "open-door" policy and eliminating the central government's monopoly over foreign trade. Four special economic zones were set up - three in the Guangdong province next to Hong Kong and the other in the Fujian province across the strait from Taiwan. These were intended to draw in foreign capital, companies, and expertise.

The third round of reform began in 1984 and dealt with industrial development. Goods were now produced according to market forces rather than through administrative policies. Also, prices were made to reflect the true market value of commodities. The government reduced the number of commodities subject to price control. 
As a result, competition spread through the economy from many sources (Wu R. 1998). One source is from foreign trade and investment, but a bigger source appears to be the inter-provincial rivalry brought about by the decentralization of economic power. Provinces are striving to out due each other not just in attracting foreign investments, but in designing and carrying out models of market reform. As a result of this, smaller firms are growing while state-owned firms that accounted for $78 \%$ of China's industrial output in 1978 now account for less than $20 \%$ (Economist, 2000).

Special Economic Zone: Special Economic Zones (SEZ) are development zones created by the government foreign expertise and the promise of future tax revenues. The SEZs offer foreign investors significant tax concessions during the early life of new projects.

Economic Growth: While commonly recognized as the most populous country with more than 1.3 billion people, China also represents one of the fastest growing economies - with GDP growing between 7.5 and 9.5 percent annually over the past 7 years - and GDP per capita growth exceeding 10 percent. Although many economists do not foresee these rates as sustainable, the Chinese economy and the population's purchasing power will continue to grow nonetheless. Despite its positive current account balance, china's rate of importing goods has increased dramatically since it acceptance into the WTO in 2001 and it is expected to continue at double-digit rates (HSBC, 2005).

Foreign Direct Investment: Foreign direct investment (FDI) in China has undergone a rapid growth since 1992 (Wattanavitukul, 2000). The nation registered actual FDI of \$25.91 billion in the first five months of 2005, up 11.34 percent year-on-year, according to the Ministry of Commerce.

The sectoral distribution of FDI in China has witnessed important changes (ADFAT 1997-2000). In the early reform period, the investment was mainly concentrated on labor-intensive manufacturing and real estate. From 1990s on, it rapidly extended to almost every field of the economy. By 2000, industry and services accounted for 60.87 percent and 37.31 percent of the total cumulative contractual investment respectively. In the second half of the 1990s, while FDI in traditional labor-intensive manufacturing industries saw stagnation, the IT industry became a new focus of investment. Foreign-invested operations in China contributed to about fifty percent of the exports which resulted in foreign exchange reserves of about $\$ 610$ billion in 2004 (U.S. State Dept.).

\section{MAJOR CHALLENEGES AND CONCERNS REGARDING DOING BUSINESS WITH CHINA}

While China offers many opportunities and prospects, there are issues of concern and potential risks facing foreign investors in that nation. This paper will address such concerns by examining and evaluating the following selected critical areas to probe the risks of doing business in China:

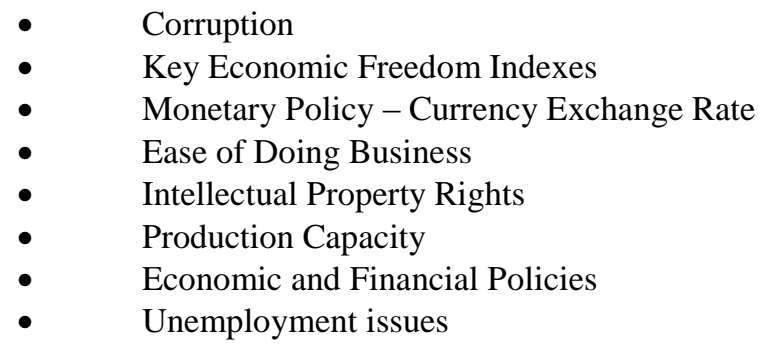

Corruption: It is well-known that China's corruption problem has become more and more serious during the period of economic reform (Friedl Business Information, 2003). The corruption index for China is registered at 8.33 - on scale of 1 to 10 , with 1 to be the least corrupt - and the magnitude of corruption ranges from 3 to 5 percent of the GDP (Forney, 2004) however, some estimate that it could be as high as 15 to 20 percent of the GDP (Weiding, 2003). 
Also, according to Corruption Perception Index (CPI) (Transparency International, 2005), China was ranked 82 among the selected countries ( 1 to be the least corrupt) due to ongoing cases of alleged corruption in various part of the country. China's low standing as a "transparent" country has also contributed to perception of investment risk in China. According to "Opacity Index" for selected economies, China has and index of 6.49 - out of 10, with 1 to be most transparent - behind Russia. It is important to note that there has been a regressive trend in CPI index for China as the country was ranked 66 in 2003 and 71 in 2004 (lower ranking indicates less corruption).

Key Economic Indexes: A number of reports and studies put China in an undesirable category for possible investment or trade consideration. The latest Economic Freedom Index (2006), ranks China 111 (out of 155) countries as "Mostly Unfree". The ranking is based on multiple economic categories with scores of 1 (free) to 5 (repressed). The overall average score for China is 3.34 with the following details:

\begin{tabular}{|ll|}
\hline China's Selected Economic Freedom Indexes \\
\hline 1 - Free & $\mathbf{5}$ - Repressed \\
Trade Policy & 3.0 \\
Fiscal Burden & 3.9 \\
Government Intervention & 3.0 \\
Monetary Policy & 1.0 \\
Foreign Investment & 4.0 \\
Banking and Finance & 4.0 \\
Wages and Prices & 3.0 \\
Property Rights & 4.0 \\
Informal Market & $\underline{3.5}$ \\
Average Score & $\mathbf{3 . 5}$ \\
\hline
\end{tabular}

Source: Economic Freedom Index (2006)

Ease of doing Business: The ease of doing business index (World Bank Group, 2006), ranks economies from 1 (easy) to 155 (most difficult). The rankings are based on the simple average rankings of multi-factor indexes to rate each country for ease of conducting businesses. Out of 155 countries, the overall rank for China is 91, indicating that establishing and doing business in China would be more challenging than in most other countries. However, in certain areas, China ranks more favorable than many other countries. The following is a listing of selected indicators:

\begin{tabular}{|lc|}
\hline Selected indicators for Ease of Doing Business In China \\
1 - Easy & $\mathbf{1 5 5}$ - Most Difficult \\
& 126 \\
Starting a Business & 136 \\
Dealing with Licenses & 87 \\
Employing & 24 \\
Registering Property & 113 \\
Getting Credit & 100 \\
Protecting Investors & 119 \\
Paying Taxes & 48 \\
Trading Across Borders & 47 \\
Enforcing Contracts & 59 \\
Closing a Business & $\mathbf{9 1}$ \\
\hline Average Rank & \\
\hline
\end{tabular}

Source: World Bank Group (2006) 
Currency Exchange Rate: An undervalued Yuan makes U.S. exports to China more expensive, affecting jobs in industries that export. It also makes imports from China cheaper to U.S. consumers, displacing employment in import-competing industries.

China is the largest contributor to the U.S. current balance of trade deficit. An undervalued Yuan encourages production to move to China from countries whose currencies have appreciated. Consequently, the total U.S. imports continue to rise. With Yuan pegged to the dollar, when the dollar weakens against major currencies such as Euro and Yen, the China's currency also falls against these currencies and hence causing potential threat in weakening the European and/or Japanese economies and, eventually, posing serious challenges for the global economy.

Intellectual Property Rights: The lack of legal protection for intellectual property rights is an often-cited risk by companies that are very cautious to their approach in the Chinese marketplace. While sectors such as software and entertainment receive a lion-share of attention, the problem extends to "copy-catting" in manufacturing, clothing, pharmaceuticals, and even fast-food restaurants and retail operations.

The rate of software piracy in western countries ranges from 22 percent in the U.S. to 35 percent in Europe. However, China's rate of piracy is at 90 percent level which ranks among the worst world-wide. The total value of economic losses exceeds those of any country and was estimated to be in excess of $\$ 3.5$ billion in 2004 (BSA, 2005).

China leads in DVD piracy rate (95 percent), with estimated losses to industry at $\$ 178$ million in 2003 (MPAA, 2005). Attendance at openings of American movies in China is typically below expectations. This is attributed to the speed with which illegal copies of the DVDs are duplicated and made available at piracy outlets (Buckley, 2003). Additional examples of copy-cat manufacturing such as Chevy cars, Honda motor cycles, fake KFC restaurants and etc. are routinely uncovered, with prices undercutting the legitimate goods.

Excess Capacity in Industrial Sector: In 1995, the utilization of production capacity in several industries was less than 50 percent and it has continued to worsen in recent years. In addition, too many steel companies have added too much capacity, driving down the price they can charge for their products. This is because not enough adequate mechanisms exist to control the issues of exit, take-over, or bankruptcy.

Poorly performing state-owned enterprises still exist and it is difficult to declare them bankrupt. Furthermore, social security systems are not well established and the mobility of capital and labor remains low in most areas of China.

Export Dependence Economy: Export dependence of China continues to grow. In 1978, exports accounted for only 5 percent of GDP and this increased to 21 percent in 1997 (Contrast this with 12 percent in U.S.). However, due to increasing competition in the world markets as well as increasing trade frictions, coupled with a decline in the economy of China's main trading partners (i.e. Japan) China may find it difficult to maintain its high export growth.

Problems with Banking Sector: China's banking sector continues to be poorly managed and regulated, with more than 22 percent of bad loans in state commercial banks (Sepehri, 2006). The same situation also exists in stock market. Due to increase in the complexity of China's economy, there is a need to pursue reforms in the banking sector.

Potential Unemployment Problem: China's unemployment problem will become more serious by 2010 (Wu, 1998). Around 10 million new workers join the labor force annually and this is coupled with the increasing number or workers needing to be laid off as state enterprise reform continue. The industrial sector is the fastest growing segment of the economy, but even its ability to absorb the surplus labor remains in doubt. 


\section{OPPORTUNITIES AND LURE OF DOING BUSINESS WITH CHINA}

While companies who seek doing business with China may face certain risks, there are numerous potential business and investment opportunities in China. The Chinese economy continues to grow at high rate and the outlook for consumer market growth and GDP are very promising. In 2005 alone, China emerged as the third largest trading nation. The GDP growth continued at a healthy rate of 9.5 percent and the government took serious actions to cool off the economy and to ease any potential for inflation.

Many major international and global corporations have - and continue to - made substantial investments in China in recent years. In fact, the FDI in 2004 rose to $\$ 63.63$ billion, a 13.32 percent increase compared to previous year.

This segment will evaluate the following selected key success factors (KFS) and will examine the underlying policies and reforms that help and enhance the business opportunities in China.

$\begin{array}{ll}- & \text { Economic Growth and Development } \\ \text { - } & \text { China and WTO } \\ \text { - } & \text { Infrastructure Development } \\ \text { - } & \text { Economic Power and other Economic Indicators }\end{array}$

China's Economic Development: Under its $10^{\text {th }}$ five-year plan $(2001-2005)$, China will continue with economic reform, adjusting the structure of its agricultural and rural economies, upgrading the industries and accelerating the pace of urbanization. The plan targets real GDP growth of 7 percent per year (Hongpin, 2005). Other targets include:

- $\quad$ Controlling population growth at below .9 percent.

- $\quad$ Controlling the urban unemployment rate at about 5 percent.

- Improving social security system and reducing income disparities among regions.

- $\quad$ Achieving per capita GDP of RMB¥9,400 by 2005 and average annual growth of about 5 percent in disposable income per urban resident and gross income per rural resident.

- $\quad$ Participating in international economic cooperation and balancing the trade account.

It is however, significant to note that the real GDP growth for 2005 was reported to be 9.9 percent (ranked $2^{\text {nd }}$ ) for mainland China and 12.4 percent (ranked ${ }^{\text {st }}$ ) for Zhejiang (IMD, 2006).

China's Entry into World Trade Organization (WTO): Since entry into WTO, China has made substantial market access commitments that include:

- $\quad$ Eliminating import license requirements and phasing out all import quotas before 2006.

- $\quad$ Cutting average import tariffs on industrial products to 9.3 percent and agricultural products to 15 percent and granting the right to conduct foreign trade to all enterprises in 2005.

- Relaxing foreign investment restrictions on many import services industries, including distribution, financial, telecommunications, and professional services.

Infrastructure Development: In a middle-income country like China, with tremendous potential for economic growth, the national infrastructure struggles to keep pace with demands. The Chinese government plans to spend billions in the coming years to improve transit, energy, telecommunications, and other vital infrastructure systems.

The energy sector exemplifies China's infrastructure growth and - with this growth - the opportunity for foreign companies to seek a share of the market - technology, products and services - in energy-related sectors. China is the world's largest producer of coal, and is now the second largest producer of electricity (behind U.S.). China's electric power production capacity has grown from $217 \mathrm{GW}$ in 1995 to $338 \mathrm{GW}$ in 2002. With electricity 
demand projected to grow at a rate of 4.3 percent through 2025, this pace of capacity expansion will continue (EIA, 2004). Furthermore, in 2003, China approved the construction of an additional $22 \mathrm{GW}$ of capacity in 30 separate projects. These, however, do not include more than $30 \mathrm{GW}$ already under construction. Also, a steady series of nuclear plants will continue to be brought on line through 2010 (Clayton, 2005).

Impact of China's Market Reform: As stated earlier, by 1970s, China adopted a capitalistic approach to help its economic growth. As a consequence of it market reform, China's economic growth rate in the past three decades has been among the highest recorded for any country during any period of world history. By some estimates, it has averaged nearly 9 percent annually since the beginning of reforms in 1978 and about 40 percent of this growth has been from increases in capital goods (Forbes, 2003). China's private sector now accounts for 60 percent of China's GDP (Forbes).

Expanded output and income have boosted domestic savings and investments, and rising personal income has attracted more foreign direct investments. Also, the rapid expansion of China's international trade has accompanied the expansion in its export market.

Economic Power and Other Indicators: China is now the world's fourth largest economy, with per capita GDP of over $\$ 1000$ and exchange reserves of about $\$ 1$ trillion. China has already surpassed United States as the leading destination for FDI. To maintain the pace of economic growth, Chinese government has introduced new government policies to deal with social issues and disparities between rural-urban areas. Furthermore, the government is trying to introduce creative business solutions to ease the difficulties of conducting business in China.

China is ranked 19 - among the top 20 (out of 61 nations) - in Overall Competitiveness Scoreboard (The IMD world Competitiveness Yearbook Scoreboard 2006). The factors measured for score include Economic Performance, Government Efficiency, Business Efficiency, and Infrastructure. It is noteworthy to observe that, China ranked 31 in 2005 and the new ranking indicates a +12 change which was the highest improvement among all nations.

\section{SUMMARY CONSIDERATIONS: WHAT HOLDS IN THE BALANCE}

China's rapidly expanding economy, and the resulting growth in the purchasing power of Chinese consumers, are factors fueling western corporations' drive to establish solid footholds in this emerging marketplace. These companies believe that, in spite of the uncertainty associated with operating in China, they are compelled to establish operations and relationships in the country, so as not to forfeit market share to their competitors.

Although economic growth in China continues to grow at a high rate, challenges exist and warnings are issues by number of economists. Ironically, the current rate of growth in GDP - at 11.3 percent - is considered by some to be "too fast" (too much growth) and harming the future economic growth in China (Jubak, 2006). While there may be other challenges and issues of concern regarding doing business in China, there may also be substantial positive signs to support investment decisions.

Despite inherent risks and possible setbacks in seeking business and investment prospects in China, there are many incentives for multinational firms to evaluate business opportunities and potential benefits in investing in this market. In China, the domestic savings and investments have continued to grow and the expansion in capital goods has further increased productivity, output, and income. Per capita income has also increased steadily - at an annual rate of 8 percent since 1980 - and Chinese per capita purchasing is currently estimated to be equivalent of $\$ 3000$. These are all considered to be the positive indication of the opportunities for market growth in China.

There are other significant indicators that should be weighed in considering doing business in or with China. It is very important to be careful how to read and interpret the economic data for China. For example, many economic and statistical sources provide separate reports for Mainland China, Hog Kong, and Zhejiang. In many cases, while some indicators (i.e. Economic Freedom Index) may seem unfavorable for China - as in mainland - they may be very favorable for either Hong Kong or Zhejiang. The following is a sample of the case: 


\begin{tabular}{|c|c|c|}
\hline \multicolumn{3}{|c|}{ Selected Indicators and Rankings for Various Regions in China } \\
\hline \multirow[t]{4}{*}{ Ease of Doing Business } & Rank & Country / Region \\
\hline & 1 & Hong Kong \\
\hline & 19 & Zhejiang \\
\hline & 91 & China - Mainland \\
\hline \multirow[t]{3}{*}{ Competitiveness } & 2 & Hong Kong \\
\hline & 19 & China - Mainland \\
\hline & 33 & Zhejiang \\
\hline \multirow[t]{3}{*}{ Real GDP Growth } & 1 & Zhejiang \\
\hline & 2 & China - Mainland \\
\hline & 8 & Hong Kong \\
\hline \multirow[t]{2}{*}{ Economic Freedom } & 1 & Hong Kong \\
\hline & 111 & China - Mainland \\
\hline
\end{tabular}

Sources: Economic Freedom Index (2006) \& World Bank Group (2006)

Most investors will look into regions such as Hong Kong, Zhejiang, shanghai, and other designated areas for business development. Consequently, they may experience a much more receptive and easier environment for business investment.

In final analysis, it is natural that any investment consideration should investigate and consider the elements of risks associated with such decision. However, in case if China, the potential opportunities would definitely prevail over the risks at this time.

\section{AUTHOR INFORMATION}

Dr. Hassan Pordeli is a Professor of Economics and Finance. Pordeli joined the JU faculty in 1983. He served as Assistant to the Dean of the College of Business in 1992. He served as Interim Dean of the school for two years. Pordeli was appointed Dean of the College of Business from June 1995 to June 1996. He was named Prudential/JU Professor of the Year in 1993-1994. Pordeli holds a B.S in Industrial Management. He earned his M.A. and Ph.D. in economics from the University of Nebraska-Lincoln. Pordeli named one of the "20 Outstanding Young Men of America" in 1985 and has received the City of Jacksonville Award for Outstanding Contributions to the Community and Citizens of Jacksonville.

Dr. Mohamad Sepehri (Dr. Mo) is the Division Chair and professor of Management and International Business at Davis College of Business, Jacksonville University. He has a unique combination of academic and business experience, with extensive background in strategic management/leadership and broad experience in international and global business operations. Dr. Sepehri has extensive scholarly researches that have been presented at national as well as international forums. He has written numerous research papers that were published in professional and refereed journals. Dr. Sepehri has also been recognized by other professional and scholarly bodies. He has been acknowledged in the Journal of Operations Management (JOM) as an "outstanding contributor" on several occasions.

\section{BIBLIOGRAPHY}

1. Australian Department of Foreign Affairs and Trade, China Infrastructure: Sectoral Plans, Reforms, and Financing, July 1997.

2. Buckley, Chris, Helped by Technology, Piracy of DVDs Runs Rampant in China, New York Times, 18 August 2003. 
3. Business Software Alliance, Second Annual BSA and IDC Global Software Piracy Study, May 2005.

4. Capitalism with Chinese Characteristics, Economist, June 1992

5. Clayton, David, Demand for Electric Power in China Still Outstrips Supply, ARC Advisory Group, July 2005.

6. Doebele, J., Chinese Capitalism Gets a Face, Forbes, May 2000.

7. Doing Business, Benchmarking Business Regulations, doing Business in 2006: Economy Rankings, 2006.

8. Energy Information Administration, China analysis Brief, U.S. Department of Energy, July 2004.

9. $\quad$ Forney, Mathew, Trouble Brewing, TIME Asia, 10 May 2004.

10. Friedle Business Information, China's Corruption Crackdown, www.friedlnet.com, 16 March, 2003.

11. General Electric Press Releases, March 6, 2003, Septemebr 16, 2004, and July 15, 2005.

12. Heritage Foundation/Wall Street Journal Report, Economic Freedom Advances: Index of Economic Freedom, January 2006.

13. Hill, Charles, International Business: Competing in the Global Marketplace, $6^{\text {th }}$ Ed, McGraw-Hill, 2006.

14. Hongpin, Qu, China Economic Outlook, HSBC, March 2005.

15. Hood, Marlowe, Steal this Software, IEEE Spectrum, July 2005.

16. Investment Promotion Network, Hong Kong and shanghai Banking Corporation Limited, March 29, 2005.

17. IMD World Competitiveness Center, World Competitiveness Yearbook Scoreboard, 2006.

18. Jubak, Jim, China's Economy is Out of Control, Jubak's Journal, MSN Money, July 2006.

19. Latourette, KS, A Short History of the Far East, $4^{\text {th }}$ Ed, MacMillan Company, New York, 1994.

20. Lixin, Wan, Face to Face - Anders Johnson, China International Business, June 29, 2005.

21. Marc, Miles, et. al., 2006 Index of Economic Freedom, Washington D.C.: The Heritage Foundation and Dow Jones \& Company, Inc., 2006.

22. McConnell, CR, Brue, SL, Economic Principles, Problems and Policies, 15 ${ }^{\text {th }}$ Ed, Mc-Graw Hill, NY, 2002.

23. Motion Picture Association of America, Anti-Piracy Report, July 2004.

24. PRC General Administration of Customs, China's Custom Statistics, 2002.

25. Schuman, Michael and Ressner, Jeffrey, Disney's Great Leap into China, TIME, July 18, 2005.

26. Thunderbird Garvin School of International Management, Anheuser-Busch and Harbin Brewery Group of China, 2005.

27. Tomich, Jeffrey, Peabody Dips its Toe into China's Economy, St. Louis Post-Dispatch, July 12, 2005.

28. Transparency International, Corruption Perception Index (CPI), 2004.

29. Transparency International, Corruption Perception Index (CPI), 2005.

30. U.S. - China Economic and Security Review Commission, China Currency Exchange Rate Problems: Facts and Policy, May 9, 2005.

31. Wattanavitukul, P., China: the Dragon Awakens, Asia Pacific Management Forum, February 2000.

32. Wattanavitukul, P., Marketing in China, Asia Pacific Management Forum, May, 2002.

33. World Economic Forum, China Business Summit: Sustainable Growth Through Innovation, 2006

34. Wu, R., China's Macro-Economy: Review and Perspective, Journal of Contemporary China, 1998.

35. Zhang, Jessy, GE Seeing Fruits of hard Labor, China International Business, March 1, 2005. 
NOTES 